\title{
Human Remains as Documents: Implications for Repatriation
}

\begin{abstract}
Purpose: The purpose of this paper is twofold. Firstly, to investigate the documentality of human remains in museum and research collections. Secondly, to provide a rationale for a processual model of documentation, which can account for their repatriation and eventual burial.
\end{abstract}

Design/methodology/approach:

This paper uses a multidisciplinary approach to examine the repatriation issue. It considers an ethical argument developed to support claims for repatriation: the nominal identification of a body as a universal criterion for its burial. Based on Igor Kopytoff's processual model of commoditisation, it looks to cultural anthropology to help explain how objects can move between a document and non-document state.

Findings: Human remains can be understood as examples of information-as-thing. However, while document theory can readily account for the expanding realm of documentation, it cannot adequately accommodate instances where documentality is revoked, and when something ceases to be a document. When a human biological specimen is returned, the process that made it serve as a document is effectively reversed. When remains are interred, they revert to their primary standing, as people. The process of becoming a document is therefore not unidirectional, and document status not permanent.

Research limitations/implications:

The implications of a processual model of documentation are discussed. Such a model must be able to account for things as they move into and out of the document state, and where the characteristics of documentality change through time.

Originality/value: This paper explores problematic material not usually discussed in relation to document theory. The repatriation movement poses a challenge to a discourse predicated on documentation as a progressively expanding field. 


\section{Introduction}

In September 2017, The Guardian newspaper ran a story about the skull of an unknown Australian soldier on display in the Mütter Museum of the College of Physicians of Philadelphia (Daley, 2017). The skull, a gruesome and tragic specimen from the First World War, showed evidence of appalling facial trauma, including a bullet lodged in the right sinus. Based on records detailing the provenance of the skull, historians were able to identify the remains. Private Thomas Hurdis, from New South Wales, died of wounds on 3 October 1917, following the Battle of Polygon Wood in Belgium. Private Hurdis was treated at an American field hospital by W.T. Shoemaker, a surgeon and ophthalmologist from Philadelphia, before dying of his wounds. Hurdis's skull was severed from his body for pathological study, "to enable physicians to learn from the medical developments and experiences of World War One” (Chester, 2018). After the war, Shoemaker donated the skull to the Mütter Museum. Following calls for the skull's repatriation, including requests from the Australian government, the specimen was finally interred in Hurdis's grave in Belgium, along with his substantive remains.

The case of Private Hurdis is not unusual. When claimants seek the repatriation of human remains held in museum and research collections, it is usually to bury (or rebury) these remains. The repatriation of human remains emerged as an issue in museology in the 1970s. It was during this period that some Indigenous groups, particularly in Australia, North America, and New Zealand, began to ask museums for the return of their ancestral remains (Fforde, 2013, p. 710). This issue was controversial from the outset, not least because many of these remains had been collected within a colonial or frontier context, often illegally or unethically (Turnbull, 2007; Pickering, 2008). Most historical specimens in museum collections were attained between 1860 and 1920, when interest in evolutionary biology was widespread. Osteological material, especially skulls, was thought to provide direct evidence about humankind's evolutionary genealogy. However, as Paul Turnbull as shown, many older specimens "were acquired in the pursuit of other, earlier avenues of scientific curiosity" (Turnbull, 2017, p. 3). These remains were collected to support now outmoded theories of racial science, in which human crania was used to validate notions of racial diversity and hierarchy. 
Indigenous ancestral remains have been the focus of most repatriation campaigns. As Hubert and Fforde have noted, "Indigenous groups request the return of the human remains of their ancestors for a number of reasons, but primarily on the grounds that their ancestors must be accorded funerary rituals appropriate to their cultural beliefs” (Hubert and Fforde, 2003, p. 2). The ethics of collecting and displaying human remains, however, is not confined to material belonging to Indigenous peoples. Jenkins mentions a campaign by a British neopagan community, seeking the repatriation of ancient (pre-Christian) remains held in British museums (2010, p. 4). As will be discussed, the morality of displaying Charles Byrne’s skeleton, in the Hunterian Museum of the Royal College of Surgeons, has also been called into question. However, this paper is not primarily about the legal or professional aspects of the repatriation and reburial movement. Nor does it focus on debates about the contested ownership of key collections or specimens, or consider the pros and cons of repatriation from a curatorial perspective. A wealth of literature already exists in this area, for example Fforde (2004, 2013), Hubert and Fforde (2003) and Joyce (2003). Rather, this paper explores the documentality of human remains. It considers a philosophical argument developed to support claims for repatriation: the naming of a body as a universal criterion for its burial (Charlier, 2014).

In a museum context, human bodily remains are viewed as physical specimens. They manifest information about anatomy, archaeology, or a related discipline. Although human remains can be readily conceived of as object-based documents, their repatriation and burial raise important theoretical issues for document theory. Since Paul Otlet, document theory has been predicated on the progressive expansion of the document category. However, when human remains are returned, their documentality is effectively extinguished. When human biological specimens are buried, often with funeral rites, they revert to a non-document state, as people. A new understanding of the process of documentation is therefore required for problematic material of this type.

Unlike books, which were made to be documents, human remains in museum and scientific collections were not born as documents. Status as a document is therefore not a 'natural' or 'essential' quality of human bodily material. Rather, document is an attribution given by someone (e.g. a physician or a scientist) to these remains. The question of how or why something can become a document is beyond the scope of this paper but, suffice it to say, this problem is not unique to document theory. The institutional theory of art, for example, has long emphasised the institutional nature of art; here, the role of the art world is 
key to attributing art status to 'readymade' things not manufactured as works of art (Dickie, 1974). Reception, rather than production, is therefore central to this concept of document. According to this 'functional' account of documentation, any object "can be made into or presented as a document.” (Buckland, 2018, emphasis original).

However, if something can so easily be made into a document, can something also be made to not function in document terms? This idea has recently come to theoretical attention (Kosciejew, 2019). The following paper pursues a similar line of enquiry and argues in favour of a processual model of documentation. Such a model must be able to account for things as they move into and out of document status, and where the characteristics of documentality change through time. This paper takes a multidisciplinary approach. It looks to cultural anthropology for a conceptual model, in particular, Igor Kopytoff's processual model for commoditisation. Commoditisation, says Kopytoff, “is best looked upon as a process of becoming rather than as an all-or-none state of being” (Kopytoff, 1986, p. 73).

This paper begins with a brief discussion of human remains and documentation. While this material can be categorised as information-as-thing, the collecting of human material is complex and controversial. Because of their primary standing as people, human bodily remains are not the same as other specimens or artefacts. Philippe Charlier's argument for the repatriation of human remains, based on their nominal identification, is examined. However, the naming of a body is not the only grounds for burial. Many historical Indigenous remains, for example, will never be formally identified, despite being culturally identified as 'ancestors' by their descendant communities. The implications of a processual model of documentation are discussed in the concluding section. Repatriation is viewed as a reversal of the process whereby a body or a body part was made to serve as a document. This action shows that the process of becoming a document is not unidirectional, and the document designation is not permanent. Human remains can move between document and nondocument states.

\section{The expanding realm of documentation}

There is a rich body of literature dedicated to the theory of documents and documentation (Lund, 2009). Much of this literature can be characterised as rationalist and positivist, since it is primarily concerned with devising scientific systems for managing the proliferation of 
information in advanced industrial societies. The need to store and organise the massive abundance of ‘documents’ produced by modern science and bureaucratic administration was a practical concern for librarians and other information professionals, tasked with managing the stuff of information. The literature of documentation was therefore born of practical necessity. However, the need to classify and categorise documents also raised broad ontological questions. Efforts to manage the rising tide of documents became increasingly challenging as the document category became progressively more inclusive (Buckland, 1997). Paul Otlet, often considered the father of information science, saw no practical or theoretical reason for limiting documents to printed or written texts. The document, as Otlet conceived it,

Was not restricted to what is written. A document is anything that represents or expresses an object, a fact, an impression by means of any sign whatsoever. Documents could be written or printed, pictorial or ideographic - the charts, plans, schemas, diagrams that held such a special place in Otlet's thinking. Threedimensional objects of the kind found in museums, such as specimens, models and so on, are documents, and so are monuments in that they have representational and evidential functions. (Rayward, 2016, p. 14)

There is consensus among theorists of documentation that the document category has grown to include an enormous variety of signifying things. Lund and Buckland have described the progressive expansion of the document concept: "If printed works [were documents], then also manuscripts; if manuscripts, then also maps and images; if maps, then also globes; if diagrams then also models; and so on” (Lund and Buckland, 2008, p. 161). Indeed, if the domain of documentation could be extended beyond text-bearing documents to include visual media, it could also be made to encompass three-dimensional artefacts and material culture. Following Michael Buckland's theory of information (Buckland, 1991), Kiersten Latham has outlined an argument expounding physical museum objects as examples of information-as-thing (Latham, 2012). As Latham points out, “while museum workers have traditionally not seen museum objects as 'documents,' they understand, perhaps more than most, that museum objects are involved in communication and information transfer” (Latham, 2012, p. 60). 
There is a logical progression from maps to globes. One is a printed representation of the Earth's surface, the other is a spherical model of the Earth. Although physically different, both formats embody information about the same thing. Also, both are handmade objects, or at least are manufactured by human-made technology. They "bear traces of human activity," a criterion used by Otlet to extend the document category beyond printed texts (Buckland 1997, p. 806). However, not all museum objects are manufactured artefacts; that is, fashioned by human hands or culture. Museum collections also contain examples of fauna and flora, as well as geological specimens. Are natural things documents? If, following Latham, museum objects are considered from the perspective of information-as-thing, as having the quality of imparting knowledge or communicating information, then all information-bearing objects of this type can be understood in documentary terms. A fossil is therefore a document; it has the potential to inform contemporary audiences about dinosaurs or other ancient species. Along with zoological and palaeontological specimens, museum collections also contain remains belonging to modern human beings (Homo sapiens). Ancient Egyptian mummies and iron age bog bodies, for example, are found in a variety of museums, including art and archaeology collections. The following discussion, however, will focus on human skeletal material. In particular, osteological specimens collected for the study of human anatomy and physical anthropology.

\section{Human remains as documents: the legacy of racial science}

Human bodily remains, conserved in museum and research collections, are documents. Human remains are collected to support teaching and research in a variety of fields, including medicine, physical anthropology, and archaeology. As documents, skeletal collections reveal information about osteological pathologies and congenital and developmental abnormalities. The study of bones can also provide direct evidence about dietary deficiency, as well as clues about demography and historical migration caused by societal and environmental pressures.

Information about social structures and religious customs can also be garnered from the study of human remains and funerary practices. Human remains are treated differently to other anatomical specimens. Professional protocols such as the Guidance for the Care of Human Remains in Museums, produced by the UK Department for Culture, Media and Sport, attest to the special status accorded to human biological material (DCMP, 2005). This guideline 
recommends best practice for the display, use, conservation and deaccessioning of human remains in British museums. Human remains, broadly defined, include "osteological material (whole or part skeletons, individual bones or fragments of bone or teeth), soft tissue including organs and skin, embryos and slide preparations of human tissue” (DCMP, 2005, p.10).

The systematic collecting of human bodily remains, that is, for scientific purposes, began in the late eighteenth century (Ferber and Wilde, 2011). Dutch physician, Petrus Camper (1782-1789), was among the first anatomists to use quantitative methods to study human crania. Camper's research, based on craniofacial morphology, led to his theory of facial angles, which was used to scientifically distinguish racial types. Because of their historical association with obsolete theories of racial science (Stepan 1982; Stocking 1982), many human anatomical collections are nowadays controversial. Dating from the late eighteenth century, comparative anatomists and physical anthropologists collected human bones, especially skulls, to study human racial diversity. When Darwinian evolutionary theory gained acceptance in scientific and intellectual circles, after the 1860s, there was a renewed interest in collecting human remains. This included the remains of Indigenous peoples. In the new Darwinian paradigm, human bones were studied for evidence of evolution, often by comparing the bodies of modern humans with apes and archaic hominids.

Irrespective of their theory of human origin or diversity, most ethnographic studies dating from the nineteenth and early twentieth centuries were conducted within a racist paradigm. This discourse upheld perceptions of other peoples as biologically and culturally inferior to modern Europeans (Fforde and Hubert, 2006, p. 83). Of the anatomical specimens collected by British and European collectors, the most prized samples came from the socalled primitive races. The construal of Indigenous Australians, especially Tasmanians, as 'living fossils’ made these remains particularly attractive to science (Turnbull, 2017, p. 26). Today, it is tempting to dismiss obsolete theories of racial science as pseudoscientific folly. Yet works like Richard Berry’s (1867-1962) monumental Atlas of Tasmanian Crania were once taken seriously (Berry, 1909), legitimised by institutions including universities and museums. Berry was renowned in his day as an expert in the specialist field of Tasmanian craniology.

'Race' collections were assembled by professional societies and research institutes in most Western countries. Indigenous remains were collected for the 'scientific' study of their racial characteristics. The scientific study of human remains also attracted the interest of wealthy private collectors, among them Joseph Barnard Davis (1801-1881). Davis, a British 
physician and craniologist, amassed a collection of at least 1,540 human skulls, with samples representing races from around the world. In 1867, his collection was acquired by the Hunterian museum of the Royal College of Surgeons; after the College was bombed during the blitz in 1941, the remnants of the Davis collection were transferred to the Natural History Museum (Fforde, 2013, p. 712). Davis was a 'polygenist,' which meant that he supported the view that the races were created separately and did not belong to a single human species. To support his views of racial difference, Davis devised techniques to measure cranial circumference and 'internal capacity' (that is, the volume of the cranial cavity). He described these methods in meticulous detail in Thesaurus Craniorum, a compendious catalogue of his collection (Davis, 1867).

The polygenetic argument, propounded by Davis to explain human racial variation, was contentious. Paul Turnbull has pointed out that when it came to the monogenist/polygenist debate in comparative anatomy, the British medical establishment supported the monogenetic view of racial difference, as advanced by John Hunter and Johann Friedrich Blumenbach (Paul Turnbull, 2017, p. 23). According to this theory, environmental factors accounted for human diversity. While the comparison of human remains continued to inform debates about human origins and racial differences, after 1859, with the advent of evolutionary biology, the study of skulls took on a new significance. Cressida Fforde explains how the new Darwinian theory promoted an acceleration in the acquisition of human remains. After Darwin, the focus shifted from taxonomy towards human evolution, especially evidence of evolution in the bones of modern peoples from around the world (Fforde, 2013, p. 712).

Nowadays, human osteological material is usually displayed in specialist anatomy collections, often for professional audiences. It is no longer valid in mainstream science to study and classify human beings by racial type. Of the collections of human remains assembled at the height of the race paradigm in the nineteenth century, many are now in storage and often forgotten about; as noted by Fforde, "the greatest interest in them since at least since the 1980s has been from, or instigated by, Indigenous groups requesting the return of their ancestors” (Fforde, 2013, p. 715). Writing in 1878, William Henry Flower, the Hunterian Professor of comparative anatomy and conservator of the Museum of the Royal College of Surgeons, boasted that his College contained fifty-four crania of native Australians, “a far larger series than is contained in any one collection elsewhere” (Flower, 1878, p. 8). Collection catalogues, like Flower's, play an important role in the identification 
of historical Indigenous remains. Davis's catalogue, Thesaurus Craniorum, contains twentyfour Australian Aboriginal skulls and twelve Tasmanian skulls, thus reflecting his belief that Indigenous Australians belonged to separate races.

In terms familiar to document theory, human bodily remains in museum collections are primary documents. The catalogues, thesauri, and compendia that describe and categorise these remains are secondary documents. But before these physical remains were transformed by science into objects of anatomical or anthropological information, they were someone's actual body. Using Suzanne Briet’s terminology, Ronald Day refers to "the simple ordinary fact” of a thing when describing its status before it becomes a document. After something is organised by a system of documentation, its identity and meaning changes. Once catalogued and made documentable, a thing will henceforth be taken as a sign in a discursive system (Day, 2016, p. 156). As will be seen, however, the documentation process is not one-way. A document is not a closed or permanent state of being. The repatriation and burial of human remains shows that documentality can be reversed, and in some cases annulled.

\section{Individuation and the humanisation of human remains}

When human remains become part of a museum or research collection, they undergo a type of transformation. Cressida Fforde describes a transitional process in which the 'the dead' are reconceived as 'scientific objects.' Human remains, “are transitioned from having primary standing as 'the dead' in one culture to a meaning defined by their value as "scientific object" in another” (Fforde 2013, p. 709). Re-conceptualising 'the dead' as 'scientific objects' (or documents) raises a variety of complex philosophical questions for collecting institutions. These problems are unique to the treatment of human remains, since different standards and values apply for the treatment of animal (non-human) specimens. This distinction is based on the cultural tenets of philosophical humanism. The moral worldview, which conceptually separates human bodily remains from animal remains, is also used to enforce the separation of people and things. This argument holds that human beings are subjects, not objects.

Anthropologists, most notably Igor Kopytoff, have used the conceptual polarity of individualised 'persons' and commoditised 'things' to explore the cultural forces that singularise human attributes, such as labour, intellect, creativity and biology (Kopytoff, 1986). Although intellectually rooted in classical antiquity and Christianity, Kopytoff argues 
that the separation of humans and commodities (that is, persons and things) became most salient with the onset of European modernity. For Kopytoff, the most glaring denial of human commoditisation was to be found in moral opposition to slavery. With the advent of modern industrial civilisation, people came to be viewed as the natural preserve for individuation (that is, singularisation) and things, conversely, as the natural preserve for commoditisation (Kopytoff, 1986, p. 84). "Whatever the complex reasons,” says Kopytoff, "the conceptual distinction between the universe of people and the universe of objects had become culturally axiomatic in the West by the mid-twentieth century” (1986, p. 84).

The conceptual separation of 'humans' and 'things' is not confined to the economic and social spheres. This distinction also informs ethical debates about the treatment of human remains conserved as specimens in museum collections. According to this view, human remains are people, not anatomical objects. The repatriation movement can therefore be seen as an extension of the drive to singularise human attributes, as theorised by Kopytoff. Phillipe Charlier has proposed a universal criterion for determining repatriation claims for human remains in museum collections (Charlier, 2014). Charlier's test for restitution is based on nominal identification, that is, the naming of the body. It holds that claims to repatriate a human body, or body part, should be upheld if the specimen in question can be identified as belonging to a known person. If the personal name of a skull, for example, can be established, this act of naming should be sufficient to reverse the process in which the skull was made to serve as a specimen. Nominal identification is proposed as an element supporting restitution because, "the name of an individual is undoubtedly a universal value"; naming the dead, says Charlier, “is comparable to an identified burial” (Charlier, 2014, p. 295).

Charlier's grounds for repatriation are powerful and compelling. Indeed, the naming of a human being, as a person, is perhaps the ultimate expression of human individuation and singularity. A name implies an identity and a biography, in other words, a personal life story. The naming of a human anatomical specimen, as the remains of a known person, will change the way in which that specimen is treated and perceived. Naming the dead will singularise generic human remains, thereby supporting the case for their repatriation and burial. As noted, the identification of an anonymous skull, as belonging to Private Thomas Hurdis, enabled this medical exhibit to be interred in a named grave. Recently, the case of Charles Byrne (the so-called the Irish Giant) has been the focus of ethical debates regarding the appropriateness of displaying human remains in museums. These remains are controversial, 
precisely because a significant amount of personal (biographical) information is known about Byrne.

For 200 years, Byrne's skeleton has been on display at the Hunterian Museum of the Royal College of Surgeons in London. Byrne was born in Londonderry in Ireland in 1761; he died in 1783, aged 22. He stood approximately 7 feet 7 inches tall. Byrne probably suffered from acromegaly, a disorder in which the pituitary gland produces too much growth hormone. Arguments supporting the burial of Byrne's remains are twofold (Doyal and Muinzer, 2011). The first is based on biographical details, in which Byrne himself expressed his desire to be buried at sea. Byrne wanted his remains to be laid to rest in this way to avoid being dissected by John Hunter and put on display in his famous museum. The second argument concerns misgivings about the circumstances in which the body was acquired. Byrne died in London and his body was sealed in a lead coffin. When Hunter heard about the funeral arrangements, he allegedly bribed a pallbearer to replace the body with heavy objects. Hunter may have paid as much as $£ 500$ for Byrne’s body ('J.D.’, 1953, p. 65)

Byrne's body was boiled down to the skeleton and installed in Hunter's private museum, where it generated considerable public interest. Byrne's remains have been used to support medical research; in 1909, American surgeon, Harvey Cushing, studied Byrne’s skull, observing an enlarged pituitary fossa, thereby confirming a link between acromegaly and the pituitary gland (Doyal and Muinzer, 2011). However, with DNA samples extracted from Byrne’s teeth, the complete skeleton may no longer be needed for scientific research. Legal and moral arguments have therefore mounted in support of Byrne’s burial, in accordance with his desire to be buried at sea (Muinzer, 2013).

The reburial of Truganini (also known as Trugernanner), a woman of the Nuenonne people of south-eastern Tasmania, provides an important historical precedent in the repatriation of human remains. In Paul Turnbull’s words, “Truganini endured the dubious fame in European eyes of supposedly being the last surviving 'full-blooded' Indigenous Tasmanian” (Turnbull, 2016, p. 203). Truganini's status, as the 'last living' member of her race, made her remains extremely attractive to collectors. Like Charles Byrne, she was anxious of her fate and feared that her body would be claimed by science. This fate had befallen her compatriot, William Lanne, the so-called last 'full-blooded' Tasmanian man, who died in 1869. Two years after Truganini’s death, in 1876, authorities granted the Royal Society of Tasmania permission to exhume her body, on the condition that it would not be exposed to public view, but rather, “decently deposited in a secure resting place accessible by 
special permission to scientific men for scientific purposes” (Ryan and Smith, 1976). However, after laying in store for a quarter of a century, the Society entrusted the remains to the Tasmanian Museum and Art Gallery, which had her skeleton articulated and placed on public view (Turnbull, 2016, p. 203). Between 1904 and 1947, Truganini’s remains were exhibited in a display case with Indigenous Tasmanian curios and artefacts.

This shameful episode finally ended in 1976, when Truganini was reburied. Her repatriation commemorated the centenary of her death. This followed extensive campaigning by the Aboriginal Information Service, which was formed in 1972, to assert the identity and interests of Indigenous Tasmanians. The return of Truganini's remains marked the beginning of the campaign to repatriate Australian Aboriginal remains held museum collections in Australia and around the world. Paul Turnbull described this event and its far-reaching consequences:

Finally, scattering Truganini's ashes in 1976 on the waters off Bruny Island, the ancestral country of the Nuenonne people, proved to be the beginning of long and determined campaigning by Indigenous Australians which has seen the gradual repatriation of ancestral bodily remains from Australian and overseas scientific collections. Since the mid 1970s, the remains of around 5000 people held in Australian museum and medical school collections have been the focus of repatriation negotiations. (2016, p. 205)

\section{Personalising anonymous bodies: from specimens to ancestors}

It is possible to establish the individual identify for some human remains in museum collections. Names of bodies or body parts can be revealed by provenance research, usually by searching institutional archival records or secondary documents, including collection catalogues. A skull belonging to a young Aboriginal Tasmanian female was recently identified in the anatomical collection at the Charité in Berlin (Winkelmann and Teßmann, 2018). The skull was repatriated in 2014 , following confirmation that the remains belonged to a girl named Nanny Allan. Nanny died in 1836, aged about 15 years, of meningitis. The collector, Adolph Schayer, was a German sheep breeder and botanical/zoological collector who lived in Tasmania from 1831 to 1843. In this example, identification was aided by inscriptions on the frontal bone, which provided a name ('Nanny'), an ancestry ('native of 
Kangaroo Island'), a collector ('Schayer') and a location ('van Diemensland,' that is, Tasmania). But what if human anatomical specimens are not identified, or nominally identifiable?

The clear majority of Indigenous ancestral remains will never be personally identified. Unlike Truganini and Nanny, they will remain anonymous. The naming of Indigenous remains was the exception, rather than the norm. Scientific racial discourse, of course, tended to de-personalise its subjects, by reducing specimens to either exemplars or anomalies of racial types or classes. Names are almost impossible to ascertain for remains dating from pre-contact times. Inscribed headstones and written death registries do not feature in most historical Indigenous cultures, where knowledge was transferred through oral traditions rather than textual documents.

The collecting of Aboriginal Australian remains commenced in the late eighteenth century, soon after British settlement in 1788. The demand for Australian osteological material increased in the decades after the 1860s, fuelled by interest in evolutionary biology and comparative human anatomy. The market for skulls did not decline until the early twentieth century, when the obsession with cranial morphology and metrics began to recede. At that time, the science of craniology was under challenge. In the United States, Franz Boas disputed the fundamental tenet of craniology, namely, "the inheritance of headform and the stability of intergenerational cranial shape” (Fforde 2013, p. 714). In the case of Indigenous Australians, Paul Turnbull notes that new scientific methods gradually replaced comparative morphological studies of bodily remains. By the 1920s, most scientists favoured anthropometric and blood-based genealogical research on living Aboriginal descendants (Turnbull, 2017 p. 3).

In colonial Australia, collecting networks for Indigenous remains were similar to collecting networks for zoological or botanical specimens. Reasons for collecting these remains varied, but most collectors were usually doctors, who sent bones and other artefacts home to their alma mater; crews aboard exploring ships, who collected skulls for scientific study or as souvenirs; and amateur scientists, anthropologists, missionaries, or so-called Protectors of Aborigines (Fforde and Hubert, 2006, p. 83). Remains could be easily obtained from hospitals, asylums and prisons. Unofficially, remains could also be taken from burial sites. Remains pillaged from traditional burial places were acquired by universities, museums and metropolitan patrons (Turnbull, 2017, p. 22). Today, these remains can be difficult to trace. Remains of this type will pose particular ethical and professional problems for 
collecting institutions. In most cases, the identities of these bodies will never be known. The example of the George Murray Black collection is a case in point. This collection is noteworthy, because it was assembled in modern times and is well-documented.

George Murray Black was a farmer and amateur archaeologist from Gippsland in Victoria. Between 1929 and 1950, he 'excavated' (or desecrated) numerous Aboriginal burial grounds in the Riverina district of south-eastern Australia, while searching for Aboriginal skeletons. Because these burial sites were so crudely excavated, without archaeological oversight, their precise locations and stratigraphic situation is unknown (Mulvaney, 1989, p.68). Murray Black may have disinterred bones and skeletons from as many as 1,800 individuals, making his one of the largest collections of Indigenous remains ever amassed by a single collector (Robertson, 2007, p. 117). Ages ranged from recent (post-contact) burials to remains possibly 14,000 years old. Murray Black’s motive for exhuming Aboriginal bodies is unclear, although, according to one official explanation, "this collection was made with the objective of accumulating sufficient skeletal material to be of value in osteometric studies" (Sunderland and Ray, 1959 p. 45). His excavations were encouraged and supported by professional anatomists. He donated all the skeletal material, without payment, to the Australian Institute of Anatomy in Canberra and the Department of Anatomy at the University of Melbourne. In 1989, while the repatriation of the Murray Black collection was in progress, John Mulvaney wrote:

Understandably, many Aboriginal people feel outrage and revulsion for such plundering, which was neither scientific nor according to archaeological practice and which broke normal codes of ethical behaviour. It would be illegal today. (Mulvaney, 1989, p. 68)

Since the professionalisation of modern medicine in the eighteenth century, the medical gaze has promoted an attitude of detachment and dispassion (Payne, 2007). Medical subjects, both living and dead, were objectified and viewed as specimens. Recently, this approach has been challenged by a tendency to humanise medicine. The repatriation movement extends this tendency to the dead. Skeletons in the Murray Black Collection were disassembled, and their bones classified by type. Each bone belonging to an individual ‘specimen’ was numbered to enable rearticulation. Ian Anderson, an Indigenous Australian 
physician, recalls his impressions on first seeing the Murray Black 'specimens' in the Department of Anatomy at the University of Melbourne:

These remains had lost their identity and were no longer viewed as people. Each bone was a specimen. To allow easy comparison each bone of a type was stored together. All of the shin bones, all of the skulls, all of the little fingers and so on. The numbers were so that if a whole individual was required they could be reassembled. (Anderson, 2010, p. 67)

The case of the Murray Black collection is important, not only because it provides an Indigenous perspective on the repatriation issue. This example also shows how anonymous remains can be collectively identified as ancestral remains. Ancestral remains are often personalised and referred to simply as ‘ancestors,' 'relatives,' or 'old people.' In some jurisdictions, including Australia, this designation will justify claims for repatriation. This will undo the process that saw Indigenous bodies classified as scientific documents. The repatriation of ancestral remains is viewed by descendant communities as a posthumous homecoming:

How distressing it would have been to see a cabinet opened to reveal a collection of femurs and skulls. These were not specimens, they were Ancestors, and it was only right and proper that they should be returned to their descendant communities. It was time that they should go home. (Russell, 2010, p. 60)

It takes a scientific perspective to view human remains as anatomical information. However, scientific viewpoints are conditioned by the formation of discourses or paradigms. As Michel Foucault and Thomas Kuhn have shown, scientific configurations are not static or permanent structures; indeed, knowledge is constantly changing, and scientific paradigms can transform or disintegrate over time. Phrenology and scientific racism are now looked upon as examples of obsolete discourses. Because many historical remains, especially those belonging to Indigenous peoples, were collected to support discredited theories, their ongoing conservation as biological specimens is contentious and questionable. 


\section{Conclusion: towards a processual understanding of documentation}

Since Paul Otlet, document theory has viewed the document type in progressively expanding terms, as extending beyond textual material to include all manner of things bearing signifying properties. The massive proliferation of information in modern society has enabled the document concept to become over-inclusive, and seemingly all-encompassing. Human remains, conserved in museum and research collections, are documents. They are collected, catalogued and displayed for scientific and educational purposes. When interpreted in the context of documentation, these bones and body parts can be understood as examples of information-as-thing, as objects manifesting knowledge or communicating information. However, when material of this type is repatriated and buried, its primary standing charges. Repatriated human remains, in their post-document state, become people again, or at least the mortal remains of people. To quote Philippe Charlier on this point, the restitution of human bodies "reverses the process by which they passed, years ago, from individual to scientific specimen” (Charlier, 2014, p. 295).

In other words, the repatriation of human bodily remains inverts the process whereby that material became a document. This action shows that the process of becoming a document is not unidirectional. Indeed, as revealed by these examples, the document concept is not a permanent designation. It can be retracted. However, the repatriation issue not only challenges the notion of the document as a stable signifying entity. It also calls into question the epistemology of document theory, especially its positivist and rationalist roots (Hjørland, 2005). Until recently, there has been a tendency to characterise the growth of information in cumulative and progressive terms. An alternative model is therefore needed to explain problematic material of this type. Such a model would have to account for circumstances in which things change through time, and where things move between document and non- 
document states. A processual understanding of documentation, like that proposed by Kopytoff for commoditisation, may help to explain this situation. The merits of this model are summarised by Arjun Appadurai:

Of the many virtues of Kopytoff's model the most important, in my view, is that it proposes a general processual model of commoditization, in which objects may be moved both into and out of the commodity state. (Appadurai, 1986, p. 17)

In principle, a processual model is not unfamiliar to document theory. Michael Buckland has posited an 'instrumental view' of documentality, according to which, “almost anything can be made to serve as a document, to signify something, to be held up as constituting evidence of some sort” (Buckland, 2014, p.180). But if document theory can readily account for the expanding realm of documentality, it should also be able to account for instances where documentality is reversed, and when something ceases to be a document. When theorising the pathways to commoditisation, Kopytoff uses the analogy of biography to explain this process. Things, like people, have biographies or careers. Through a system of transaction, things become commodities via a process of exchange. A thing's usefulness and value will change over the course of its lifetime, but when it reaches the end of its usefulness, its career as a commodity will end (Kopytoff, 1986, pp. 66-67). The trope of the antelope is familiar to document theory (Briet, 2006 [1951]). Suzanne Briet famously explained how a wild antelope could become a document if it was catalogued and placed in a zoological setting. Presumably, if the same animal was deaccessioned and returned to its natural habitat, it would revert to its pre-document status, as a wild antelope.

Human remains can be viewed as both people and documents. If perceived as a document, a human skeleton can be regarded primarily as a specimen, a source of 
information or evidence; if viewed as an individual, that same skeleton can be regarded first and foremost as a person. This depends on circumstances, and one designation does not necessarily exclude the other. The emphasis here is on the question of primary standing; that is, which attributes take precedence and why? When it comes to the status of Indigenous ancestral remains, cultural standing now takes precedence over scientific standing.

The role of culture and context therefore plays a crucial role in determining how human remains are perceived and treated. The discovery of the body of Richard III is a case in point. After his skeleton was exhumed in 2012, it was widely studied to yield information about the king and his life and death (Appleby et al., 2015). After this information was obtained from the bones, they were entombed in Leicester Cathedral in a named grave. The process of moving between person and document status is evident. This example can be compared and contrasted with that of Truganini. When her remains were repatriated, efforts were made to nullify their document status. To prevent them from ever being used for research again, her remains were cremated and scattered in the D’Entrecasteaux Channel.

In Kopytoff's model, commoditisation is offset by singularisation. Based on this theory, the drive to objectify human elements can be countered by an opposing drive to individuate things as people. Personalising human remains can restore individuality to generic specimens. Charlier has argued in favour of naming a body as a criterion for restitution, since, “naming is comparable to an identified burial” (Charlier, 2014, p. 295). But, of course, not all bodies can be named. And, moreover, nominal identification is not a prerequisite for a dignified burial. After World War One, the remains of unknown Commonwealth soldiers were interred under the epitaph, 'Known unto God.' The realities of colonial violence and dispossession will prevent the naming of most historical Indigenous remains. However, these remains represent unknown ancestors, in much the same way as unknown soldiers represent the collective war dead. The personalisation of ancestral remains, 
as 'ancestors,' should be grounds for repatriation and burial, especially in cases like the Murray Black collection, where remains were unethically acquired for scientific research.

Recently, Australian historian Billy Griffiths has written about the repatriation of Mungo Lady, ancient Aboriginal bones discovered in 1968 on the shore of a dry lake in remote south-west New South Wales (Griffiths, 2018, p.136). Mungo Lady’s remains could be 42,000 years old, making them among the oldest anatomically modern human remains in the world. In 1992, her fossilised remains were returned to Lake Mungo for reburial. Mungo Lady’s repatriation, however, was unusual. The remains were buried in a decorated locked safe. It requires two keys to unlock this box, one of which is held by the local Aboriginal people and the other by scientists. The safe will open only when both locks are turned together. This gesture symbolised a new partnership between scientists and Indigenous people. Mungo Lady is as example of a processual model of documentation. When the remains were taken from the laboratory and reburied, they were effectively removed from the document realm. But this is not the end of the story. There is potential that one day they might return to science, even momentarily, to help yield information about life in ancient Australia.

\section{References}

Anderson, I. (2010), “Murray Black Collection and the University of Melbourne”, in Faulkhead, S. and Berg, J. (Eds.), Power and the Passion: Our Ancestors Return Home, Koorie Heritage Trust, Melbourne, pp. 64-67.

Appadurai, A. (1986), "Introduction: commodities and the politics of value”, in Appadurai, A. (Ed.), The Social Life of Things: Commodities in Cultural Perspective, CUP, Cambridge, pp. 3-63. 
Appleby, J., Rutty, G.N., Hainsworth, S. et al. (2015). "Perimortem trauma in King Richard III: A skeletal analysis”, The Lancet, Vol. 385 No. 9964, pp. 253-259.

Berry, R.J.A. (1909), Dioptrographic Tracings in Four Normae of Fifty-two Tasmanian Crania, Government Printer, Melbourne.

Briet, S. (2006 [1951]). “What is documentation?” In R. E. Day, L. Martinet, \& H. G. B. Anghelescu (Eds.), What is Documentation? English Translation of the Classic French Text, Scarecrow Press, Lanham, MD, pp. 9-46.

Buckland, M.K. (1991), “Information as thing”, Journal of the American Society for Information Science, Vol. 42 No. 5, pp. 351-360.

Buckland, M.K. (1997), “What is a 'document’?”, Journal of the American Society for Information Science, Vol. 48 No. 9, pp. 804-809.

Buckland, M. (2014), “Documentality beyond documents”, Monist, Vol. 97 No. 2, pp. 179186.

Buckland, M. (2018), “Document theory”, in ISKO Encyclopedia of Knowledge Organization, ed. Birger Hjørland, B. and Gnoli, C (Eds.), International Society for Knowledge Organization, http://http://www.isko.org/cyclo/document

Charlier, P. (2014), "Naming the body (or the bones): human remains, anthropological/medical collections, religious beliefs, and restitution”, Clinical Anatomy, Vol. 27 No. 3, pp. 291-295.

Chester, D. (2018). “Remains of Private Thomas Hurdis re-unified”, available at: https://www.minister.defence.gov.au/minister/dchester/media-releases/remainsprivate-thomas-hurdis-re-unified (accessed 29 March 2019).

Daley, P. (2017), “The Anzac skull that tells a shocking and tragic story of battlefield violence”, The Guardian, 25 September. https://www.theguardian.com/australianews/postcolonial-blog/2017/sep/25/the-anzac-skull-that-tells-a-shocking-and-tragicstory-of-battlefield-violence

Davis, J.B. (1867), Thesaurus Craniorum: Catalogue of the Skulls of the Various Races of Man, in the Collection of Joseph Barnard Davis, London. 
Day, R.E. (2016), “‘A Necessity of Our Time’: documents and culture in Suzanne Briet’s Qu'est-ce que la documentation?”, in Rayward, W.B. (Ed.), European Modernism and the Information Society: Informing the Present, Understanding the Past, Routledge, London, pp. 155-164.

DCMS [Department for Culture, Media and Sport] (2005), “Guidance for the Care of Human Remains in Museums”, available at: https://www.britishmuseum.org/pdf/DCMS\%20Guide.pdf (accessed 29 March 2019).

Dickie, G. (1974), Art and the Aesthetic: An Institutional Analysis, Cornell University Press, Ithaca, N.Y.

Doyal, L. and Muinzer, T (2011), “Should the skeleton of 'the Irish Giant' be buried at sea?”, BMJ (Online), Vol. 343 No. 7837 [no pagination].

Ferber, S. and Wilde, S. (2011), The Body Divided: Human Beings and Human 'Material' in Modern Medical History, Ashgate, Farnham.

Fforde, C. (2004), Collecting the Dead: Archaeology and the Reburial Issue, Duckworth, London.

Fforde, C. (2013), “In search of others: the history and legacy of 'race' collections”, in Tarlow, S. and Stutz, L.N. (Eds.), The Oxford Handbook of the Archaeology of Death and Burial, OUP, Oxford, UK, pp. 709-731.

Fforde, C. and Hubert, J. (2006), “Indigenous human remains and changing museum ideology”, in Layton, R., Shennan, S. \& Stone, P. (Eds.), A Future for Archaeology: The Past in the Present, UCL, London, pp. 83-95.

Flower, W.H. (1878), The Native Races of the Pacific Ocean, Royal Institution of Great Britain, London.

Griffiths, B. (2018), Deep Time Dreaming: Uncovering Ancient Australia, Black Inc., Carlton, Vic.

Hjørland, B. (2005), “Empiricism, rationalism and positivism in library and information science”, Journal of Documentation, Vol. 61 No. 1, pp. 130-155.

Hubert, J. \& Fforde, C. (2003), “Introduction: The reburial issue in the twenty-first century”, in Fforde, C., Hubert, J. \& Turnbull, P. (Eds.), The Dead and their Possessions: Repatriation in Principle, Policy and Practice, Routledge, London, pp. 1-16. 
'J.D.' (1953), “OBSERVABLES at the Royal College of Surgeons. 42. Charles Byrne, the Irish giant”, Annals of the Royal College of Surgeons of England, Vol. 13 No. 1, pp. 63-65.

Jenkins, T. (2011), Contesting Human Remains in Museum Collections: The Crisis of Cultural Authority, Routledge, New York.

Joyce, R. A. (2003), “Academic freedom, stewardship and cultural heritage: weighing the interests of stakeholders in crafting repatriation approaches”, in Fforde, C., Hubert, J. \& Turnbull, P. (Eds.), The Dead and their Possessions: Repatriation in Principle, Policy and Practice, Routledge, London, pp. 99-107.

Kosciejew, M. R. H. (2019), “Considering a non-document: concepts, components, and contexts”, Journal of Documentation, Vol. 75 No. 3, pp. 627-642.

Kopytoff, I. (1986), “Cultural biography of things: commoditization as process”, in Appadurai, A. (Ed.), The Social Life of Things: Commodities in Cultural Perspective, CUP, Cambridge, pp. 64-91.

Latham, K.F. (2012), “Museum object as document: using Buckland's information concepts to understand museum experiences”, Journal of Documentation, Vol. 68 No. 1, pp. 45-71.

Lund, N.W. (2009), “Document theory”, Annual Review of Information Science and Technology, Vol. 43 No.1, pp. 399-432.

Lund, N.W. and Buckland, B. (2008), “Document, documentation, and the Document Academy: introduction”, Archival Science, Vol. 8 No. 3, pp. 161-164.

Muinzer, T.L. (2013), “A grave situation: an examination of the legal issues raised by the life and death of Charles Byrne, the 'Irish Giant'”, International Journal of Cultural Property, Vol. 20 No. 1, pp. 23-48.

Mulvaney, J. (1989), “Reflections on the Murray Black Collection”, Australian Natural History, Vol. 23 No. 1, pp. 66-72.

Payne, L. (2007), With Words and Knives: Learning Medical Dispassion in Early Modern England, Ashgate, Aldershot.

Pickering, M. (2008), “Lost in Translation”, Borderlands: e-journal, Vol. 7 No. 2, pp. 1-18. 
Rayward, W.B. (2016), “Introduction: European modernism and the information society: conceptual interdependence”, in Rayward, W.B. (Ed.), European Modernism and the Information Society: Informing the Present, Understanding the Past, Routledge, London, pp. 1-25.

Robertson, S. (2007), "Sources of bias in the Murray Black Collection: implications for palaeopathological analysis”, Australian Aboriginal Studies, No. 1, pp. 116-130.

Russell, L. (2010), “Reflections on Murray Black’s writings”, in Faulkhead, S. and Berg, J. (Eds.), Power and the Passion: Our Ancestors Return Home, Koorie Heritage Trust, Melbourne, pp. 56-63.

Ryan, L. and Smith, N. (1976), “Trugernanner (Truganini) (1812-1876)”, in Australian Dictionary of Biography, National Centre of Biography, Australian National University, Canberra, available at: http://adb.anu.edu.au/biography/trugernannertruganini-4752/text7895 (accessed 31 March 2019).

Stepan, N. (1982), The Idea of Race in Science: Great Britain 1800-1960, Macmillan, London.

Stocking, G.W. (1982), Race, Culture, and Evolution: Essays in the History of Anthropology, University of Chicago Press, Chicago, Ill.

Sunderland, S. and Ray, L.J. (1959), “A note on the Murray Black Collection of Australian Aboriginal skeletons”, Proceedings of the Royal Society of Victoria, Vol. 71 No. 1, pp.45-48.

Turnbull, P. (2007), "Scientific theft of remains in colonial Australia”, Australian Indigenous Law Review, Vol. 11 No. 1, pp. 92-102.

Turnbull, P. (2016), “Managing and mapping the history of collecting indigenous human remains”, Australian Library Journal, Vol. 65 No. 3, pp. 203-212.

Turnbull, P. (2017), Science, Museums and Collecting the Indigenous Dead in Colonial Australia, Palgrave Macmillan, Basingstoke, Hampshire.

Winkelmann, A. and Teßmann, B. (2018), “Identification and return of a skull from Tasmania in the Berlin anatomical collection”, Anthropologischer Anzeiger, Vol. 75 No. 1, pp. 39-47. 